\title{
Congressional Fellowship Program Announces 2011-12 Fellows
}

$\mathrm{F}$ ounded in 1953, the APSA Congressional Fellows Program is the nation's oldest and most prestigious congressional fellowship. The program remains devoted to its original objective of expanding knowledge and awareness of Congress. For nine months, select political scientists, journalists, doctors, federal executives, and international scholars gain "hands on" understanding of the legislative process by serving on congressional staffs. Through this opportunity, the association enhances public understanding of policymaking and improves the quality of scholarship, teaching, and reporting on American national politics. For more information, please visit http://apasnet.org/content_3031.cfm. Individuals selected for the proram for 2011-12 are listed below.

\section{POLITICAL SCIENTIST}

James M. Curry, PhD Candidate, University of Maryland

Janna L. Dietz, PhD, Assistant Professor, Western Illinois University

Kelly Dittmar, PhD Candidate, Rutgers, the State University of New Jersey

Harun Dogo, PhD Candidate, Pardee Rand Graduate School

Jesse T. Richman, PhD, Assistant Professor, Old Dominion University

Jordan Tama, PhD, Assistant Professor, School of International Service, American University

Christopher N. Tausanovitch, PhD Candidate, Stanford University

\section{JOURNALIST}

Peter T. Gartrell, Associate Editor, Platts/ McGraw Hill

\section{AMERICAN AUSTRALIAN \\ ASSOCIATION}

Andrew Brookes, Esq., Minter Ellison Lawyers, Australia

\section{ASIA FOUNDATION}

Natee Vichitsorasatra, PhD., Diplomatic Officer, Thailand Ministry of Foreign Affairs, Press Division, Department of Public Information
ATLANTIC PHILANTHROPIES/

HEALTH \& AGING POLICY FELLOWS

\section{Residential}

Dawn Alley, PhD, Assistant Professor, Department of Epidemiology \& Public Health, Division of Gerontology University of Maryland School of Medicine

Karon Phillips, PhD, MPH, Postdoctoral Research Fellow, Scott \& White Healthcare

Erica Solway, PhD, MSW, MPH, Program Director, Older Adult Day Support/ Community Integration Services, Family Service Agency of San Francisco

Sally Stearns, PhD, Professor, Department of Health Policy and Management

University of North Carolina at Chapel Hill

\section{Non-Residential}

Julie Bynum, MD, MPH, Associate Professor of Medicine, Associate Director of the Center for Health Policy Research, The Dartmouth Institute for Health Policy and Clinical Practice Dartmouth Medical School

Mike Fosina, MPH, FACHE, Vice President and Executive Director, New York Presbyterian/Allen Hospital

Tracie Harrison, $\mathrm{PhD}$, Associate Professor, The University of Texas at Austin School of Nursing

Lew Lipsitz, MD, Chief of Gerontology, Beth Israel Deaconess Medical Center, Director, Institute for Aging Research, Vice-President of Academic Medicine, Hebrew Senior Life, Professor of Medicine, Harvard Medical School

G. Adriana Perez, PhD, ANP (supported by the CDC), Assistant Professor and Southwest Borderlands Scholar, 20092010 John A. Hartford Foundation Claire M. Fagin Postdoctoral Fellow, College of Nursing and Health Innovation, Hartford Center of Geriatric Nursing Excellence, Arizona State University

\section{CARL ALBERT}

Caitlin Alyce O'Grady, PhD Candidate, University of Oklahoma

\section{HATFIELD FOUNDATION}

Darrell Lawrence, Property Superintendant, Stealth Development Inc.

\section{FEDERAL EXECUTIVES}

Matthew K. Asada, Office of the Special Representative for Afghanistan and Pakistan, US Department of State

Adrienne C. Izzo, Leadership Analyst, Office of Iraq Analysis, Central Intelligence Agency

Dan Marambio, Branch Chief, Acquisition and Systems Engneering, Central Intelligence Agency

Gregory E. Becker, Chief of Staff, OTC Front Office, Central Intelligence Agency

Timothy M. Boudreaux, Senior Space Integration Engineer, Office of the Secretary of Defense

\section{THE GERMAN MARSHALL FUND OF} THE UNITED STATES

Paul Philipp Maeser, Project Manager, Global Transaction Banking - Project "Erasmus"

Diana Gierstorfer, Policy Adviser, European Parliament, Secretariat of the ALDE Group

\section{ROBERT WOOD JOHNSON FOUNDATION}

Nancy Dunlap, MD, PhD, MBA, Vice Chair for Clinical Affairs, Department of Medicine, University of Alabama at Birmingham

Liana Orsolini- Hain, PhD, RN, CCRN, Nursing Instructor, City College of San Francisco

Arun Patel, MD, JD, Attorney, Manatt, Phelps \& Phillips LLP

Carole Pratt, DDS, General Dentistry, Virginia State Health Policy Institute

David Sklar, MD, Associate Dean, Graduate Medical Education 